\title{
Analisis Pengaruh Model Ekspositori Terhadap Penguasaan Konsep Siswa Pada Materi Pembelajaran Fisika
}

\author{
Safitri Dina Prameswari ${ }^{1}$, Nana $^{2}$ \\ Program Studi Pendidikan Fisika Universitas Siliwangi \\ Jl. Siliwangi No.24, Kahuripan, Kec. Tawang, Tasikmalaya 46115, Jawa Barat, Indonesia
}

\begin{abstract}
Abstrak. Fisika adalah mata pelajaran yang banyak menuntut kemampuan intelektualitas yang relatif tinggi sehingga sebagian besar siswa mengalami kesulitan mempelajarinya. Keadaan yang demikian ini lebih dipersulit lagi dengan penggunaan metode pembelajaran fisika yang tidak tepat. Tujuan pada penelitian ini adalah untuk menganalisis pengaruh model model ekspositori terhadap pengasaan konsep siswa pada materi pembelajaran fisika. Metode yang digunakan adalah metode studi pustaka (literature review). Melalui studi pustaka penelitian ini menghasilkan tahapan-tahapan model ekspositori yang dapat memantau peserta didik dalam pengasaan konsep untuk menyelesaikan permasalahan khususnya pada fisika. Kesimpulan yang dapat diambil, Model pembelajaran ekspositori adalah strategi pembelajaran yang menekankan kepada proses penyampaian materi secara verbal dari seorang guru kepada sekelompok siswa dengan maksud agar siswa dapat menguasai materi pelajaran secara optimal. Penguasaan konsep memberikan pengertian bahwa konsep-konsep yang diajarkan kepada siswa bukanlah sekedar bahan hapalan saja, tetapi konsep itu harus dipahami agar dapat digunakan untuk dapat memecahkan masalah yang dihadapi. Metode ceramah lebih efektif dan efisien untuk menyampaikan informasi dan pengertian.
\end{abstract}

Kata kunci: Model Pembelajaran, Model Ekspositori, Penguasaan konsep

\begin{abstract}
Physics is a subject that demands relatively high intellectual abilities so that most students have difficulty learning it. This situation is further complicated by the inappropriate use of physics learning methods. The purpose of this study was to analyze the effect of the expository model on students' understanding of concepts in physics learning material. The method used is the literature review method. Through literature study, this research produces stages of an expository model that can monitor students in understanding concepts to solve problems, especially in physics. The conclusion that can be drawn, the expository learning model is a learning strategy that emphasizes the process of delivering material verbally from a teacher to a group of students with the intention that students can master the subject matter optimally. Mastery of concepts gives the understanding that the concepts taught to students are not just memorizing materials, but they must be understood so that they can be used to solve the problems at hand. The lecture method is more effective and efficient to convey information and understanding.
\end{abstract}

Keywords: Learning Model, Expository Model, Concept mastery 


\section{PENDAHULUAN}

\section{A. Latar Belakang Masalah}

Fenomena pembelajaran merupakan fenomena yang sudah sejak lama ada. Sebagian besar pembelajaran pada tiap sekolah di Indonesia masih menampakkan ciri-ciri sistem belajar konvensional. Walaupun demikian, paradigma baru pendidikan yang menyusun kurikulum berbasis kompetensi berupaya melakukan perubahan sistem pembelajaran konvesional. Berbagai inovasi program pendidikan telah dilaksanakan, diantaranya perubahan kuri-kulum, pengadaan buku ajar dan pengadaan pelatihan bagi tenaga-tenaga pendidik. Semua itu diadakan karena mengingat begitu penting peranan pendidikan dalam pembangunan, dalam hal ini sebagai wadah untuk meningkatkan hasil belajar peserta didik. Oleh karena itu dalam memenuhi pendidikan yang berkualitas maka guru hendaklah memiliki peran yang bisa mewujudkan pendidikan yang diharapkan. Salah satu cara yang mesti ditempuh oleh guru adalah menerapkan inovasi akan metode-metode, pendekatan atau teknik pembelajaran sehingga mampu mewujudkan pembelajaran yang menarik sehingga memotivasi peserta didik meningkatkan dan mengakibatkan hasil belajar peserta didik juga dapat meningkat dari sebelumnya. Dengan memenuhi hal tersebut, maka untuk mencapai pendidikan yang berkualitas dapat terwujud.

Penguasaan konsep memberikan pengertian bahwa konsep-konsep yang diajarkan kepada siswa bukanlah sekedar bahan hapalan saja, tetapi konsep itu harus dipahami agar dapat digunakan untuk dapat memecahkan masalah yang dihadapi. Penguasaan konsep merupakan tingkatan hasil proses belajar seseorang sehingga dapat mendefenisikan atau menjelaskan suatu bagian informasi dengan kata-kata sendiri, dengan kemampuan siswa menjelaskan atau mendefenisikan berarti siswa tersebut telah memahami konsep atau prinsip dari bahan-bahan pelajaran, meskipun penjelasan yang diberikan susunan kalimatnya tidak sama dengan konsep yang diberikan, tetapi makna- nya tidak berbeda. (Dahar, 2011)

Fisika adalah mata pelajaran yang banyak menuntut kemampuan intelektualitas yang relatif tinggi sehingga sebagian besar siswa mengalami kesulitan mempelajarinya. Keadaan yang demikian ini lebih dipersulit lagi dengan penggunaan metode pembelajaran fisika yang tidak tepat. Guru terlalu mengandalkan metode pembelajaran yang cenderung bersifat informatif sehingga pengajaran Fisika menjadi kurang efektif karena siswa memperoleh pengetahuan Fisika yang lebih bersifat nominal daripada fungsional. Akibatnya siswa tidak mempunyai keterampilan yang diperlukan dalam pemecahan masalah karena siswa tidak mampu menerapkan pengetahuan yang telah dipelajari untuk memecahkan soal-soal Fisika yang dihadapi. Saat ini, pengajaran fisika di sekolah masih menekankan konsep-konsep fisika yang identik dengan persamaan dan rumus matematis. Banyaknya rumus dalam fisika menyebabkan banyak peserta didik yang menganggap bahwa fisika adalah mata pelajaran yang sulit untuk dipelajari. Hal ini juga berdampak pada rendahnya hasil belajar siswa untuk pelajaran fisika. Hingga saat ini, permasalahan ini merupakan masalah klasik yang sering dijumpai para guru fisika di SMA .

Masalah tersebut dapat diminimalisir melalui metode ekspositori dengan pemberian kuis dalam memecahkan masalah yang dihadapi peserta didik, sehingga motivasi dan hasil 
belajarnya meningkat dalam belajar fisika. Melalui metode ini peserta didik memperoleh pengetahuan dari guru yang sudah diolah sedemikian rupa, memberikan pelatihan dan menjawab soal-soal latihan dengan bimbingan dari guru, peserta didik lebih aktif dari guru dalam menjawab, mengemukakan pendapat, mengerjakan soal latihan dan kuis.

Mata Pelajaran Fisika memegang kontribusi yang penting bagian untuk meningkatkan mutu pendidikan, khususnya di bagian dalam menghasilkan peserta didik yang unggul dan berkualitas, yaitu peserta didik yang mampu berfikir kritis, kreatif, terstruktur dan berinisiatif bagian dalam merespon berbagai isu di masyarakat yang diakibatkan oleh dampak perkembangan ilmu pengetahuan dan teknologi.

\section{B. Rumusan Masalah}

Berdasarkan pembatasan masalah, maka rumusan masalah dalam penelitian ini sebagai berikut:

Bagaimana terdapat pengaruh model pembelajaran ekspositori terhadap penguasaan siswa pada konsep fisika?

C. Tujuan Penelitian

Mengetahui pengaruh model pembelajaran ekspositori terhadap penguasaan siswa pada konsep fisika.

\section{METODE PENELITIAN}

Pada penelitian analisis pengaruh model Creative Problem Solving (CVS) untuk meningkatkan Higher Order Thinking Skills (HOTS) siswa pada materi momentum dan impuls menggunakan metode studi pustaka (literature review). Teknik pengumpulan data menggunakan teknik dokumentasi yang bersumber dari buku teks dan jurnal. Teknik analisis data dengan cara analogi data, mensintesis data, menginterpretasi data, dan mengklasifikasikan data.

\section{HASIL DAN PEMBAHASAN}

\section{A. Model pembelajaran Ekspositori}

Model pembelajaran yang dimaksud adalah pembelajaran yang berpusat kepada guru (teacher oriented), guru sebagai fasilitator dalam pembelajaran dan mengajak siswa untuk berpikir lebih kritis pada kegiatan diskusi yang dilakukan dalam pembelajaran. Strategi pembelajaran tersebut adalah Strategi Pembelajaran Ekspositori.

Metode ekspositori adalah pengajaran yang telah diolah oleh guru sehingga siap disampaikan kepada peserta didik dan peserta didik diharapkan belajar dari informasi yang diterimanya itu. Dari metode pembelajaran yang biasa diterapkan dengan metode ceramah, 
tanya jawab dan sesekali diselingi dengan diskusi dapat ditingkatkan lagi dengan menerapkan metode ekspositori dengan pemberian kuis. (Salmawati, 2014)

Model pembelajaran ekspositori adalah strategi pembelajaran yang menekankan kepada proses penyampaian materi secara verbal dari seorang guru kepada sekelompok siswa dengan maksud agar siswa dapat menguasai materi pelajaran secara optimal. Dalam sistem ini guru menyajikan dalam bentuk yang telah dipersiapkan secara rapi, sistematik dan lengkap sehingga anak didik tinggal menyimak dan mencernanya saja secara tertib dan teratur. (Herawati, 2019)

Strategi Pembelajaran ekspositori adalah strategi pembelajaran yang menekankan kepada proses penyampaian materi secara verbal (bisa dilakukan dengan diskusi dan ceramah) kepada sekelompok siswa, agar siswa mampu untuk berpikir lebih kritis untuk menguasai materi (Sanjaya, 2011:179). Siswa dilatih untuk memecahkan masalah dengan bantuan guru pada masalah autentik. Masalah uatentik dapat diartikan sebagai suatu masalah yang sering ditemukan dalam kehidupan sehari-hari misalnya berkaitan tentang kelistrikan yang ada dirumah. Selain itu, dengan pemberian masalah yang autentik, siswa dapat membentuk makna dan bahan pelajaran melalui proses belajar dan meyimpan dalam ingatan sehingga sewaktu-waktu digunakan. Keberhasilan pembelajaran akan lebih bermakna lagi jika apa yang diperoleh dari pembelajaran dapat diaplikasikan dalam kehidupan sehari-hari.

Karakteristik pembelajaran ekspositori :

Pertama, strategi ekspositori dilakukan dengan cara menyampaikan materi pelajaran secara verbal, artinya bertutur secara lisan merupakan alat utama dalam melakukan strategi ini. Kedua, biasanya materi pelajaran yang disampaikan adalah materi pelajaran yang sudah jadi, seperti data atau fakta, konsep-konsep tertentu yang harus dihafal sehingga tidak menuntut siswa untuk berfikir ulang. Ketiga, tujuan utama pembelajaran adalah penguasaan materi pelajaran itu sendiri. Artinya, setelah proses pembelajaran berakhir siswa diharapkan dapat memahaminya dengan benar dengan cara dapat mengungkapkan kambali materi yang telah diuraikan.

Tahapan-tahapan metode ekspositori adalah : 1) Awal pembelajaran guru berbicara atau mempresentasikan materi pelajaran. 2) Selajutnya, guru menerangkan materi dan dilanjutkan dengan memberikan contoh-contoh soal. Saat pembelajaran berlangsung, mahasiswa tidak hanya mendengar tapi juga membuat catatan-catatan. 3) Selanjutnya, siswa juga membuat soal latihan dan dapat bertanya kalau tidak mengerti. Siswa saat pembelajaran sedang berlangsung dapat sambil memeriksa pekerjaan mahasiswa secara individual, kemudian bila dirasa perlu dapat menjelaskan lagi kepada mahasiswa secara individual atau klasikal.

Kelebihan dan Kelemahan Metode Ekspositori Menurut Wina Sanjaya, (2006:190-191) metode ekspositori memiliki beberapa kelebihan, antara lain:

1) Guru bisa mengontrol urutan dan keluasan materi pembelajaran, dengan demikian ia dapat mengetahui sampai sejauh mana siswa menguasai bahan pelajaran yang disampaikan. 
2) Medel ekspositori dianggap sangat efektif apabila materi pelajaran yang harus dikuasai siswa cukup luas, sementara itu waktu yang dimiliki untuk belajar terbatas.

3) Mahasiswa dapat mendengar melalui penuturan tentang suatu materi pelajaran, juga sekaligus mahasiswa bisa melihat atau mengobservasi.

4) Bisa digunakan untuk jumlah siswa dan ukuran kelas yang besar.

Adapun kelemahan metode ekspositori menurut Wina Sanjaya, (2006: 190-191) antara lain:

1) Metode ini dapat dilakukan terhadap siswa yang memiliki kemampuan mendengar dan menyimak secara baik. Untuk mahasiswa yang tidak memiliki kemampuan seperti ini perlu digunakan metode yang lain.

2) Metode ini tidak mungkin dapat melayani perbedaan setiap individu baik perbedaan kemampuan, perbedaan pengetahuan, minat dan bakat serta perbedaan gaya belajar.

3) Karena metode ini lebih banyak diberikan melalui ceramah, maka akan sulit mengembangkan keampuan mahasiswa dalam hal kemampuan sosialisasi, hubungan interpersonal, serta kemampuan berpikir kritis.

4) Keberhasilan sangat tergantung kepada apa yang dimiliki guru. Oleh karena gaya komunkasi metode ini lebih banyak terjadi satu arah (one-way communication), maka kesempatan untuk mengontrol pemahaman siswa akan materi pembelajaran akan sangat terbatas pula. Di samping itu, komunikasi satu arah bisa mengakibatkan pengetahuan yang dimiliki mahasiswa akan terbatas pada apa yang diberikan guru.

Pada umumnya guru lebih suka menggunakan metode ceramah dikombinasikan dengan metode tanya jawab. Metode ceramah banyak dipilih karena mudah dilaksanakan dengan persiapan yang sederhana, hemat waktu dan tenaga, dengan satu langkah langsung bisa menjangkau semua siswa dan dapat dilakukan cukup di dalam kelas. Menurut Hasibuan dan Moedjiono dalam Abdul Azis Wahab metode ceramah adalah cara penyampaian bahan pelajara dengan komunikasi lisan.2 Metode ceramah lebih efektif dan efisien untuk menyampaikan informasi dan pengertian. Margono dalam Hidayat mengemukakan bahwa metode ceramah adalah metode mengajar yang menggunakan penjelasan verbal. Komunikasi bersifat satu arah dan sering dilengkapi dengan alat bantu audio visual, demonstrasi, tanya jawab, diskusi singkat dan sebagainya.

Dalam proses pembelajaran dengan metode ceramah, guru harus peka terhadap respon siswa. Skiner dalam Driscoll dalam Abdul azis Wahab menjelaskan bahwa diskripsi hubungan antara stimulan dan respon tidaklah sesederhana yang diperkirakan, melainkan stimulan yang diberikan berinteraksi satu dengan lainnya, dan interaksi ini artinya mempengaruhi respon yang diberikan juga menghasilkan berbagai konsekwensi yang akan mempengaruhi tingkah laku siswa. Untuk menciptakan terjadinyan interaksi, menarik perhatian siswa dan melatih keterampilan siswa, metode ceramah biasanya dikombinasikan dengan metode tanya jawab dan pemberian tugas.

Model ekspositori terhadap penguasaan konsep siswa pada materi pembelajaran fisika:

Adapun langkah-langkah pembelajaran ekspositori, yaitu sebagai berikut (Sanjaya, 2006).

1) Persiapan 
Langkah persiapan berkaitan dengan persiapan siswa untuk menerima pelajaran. Persiapan merupakan langkah yang sangat penting. Keberhasilan pelaksanaan pembelajaran dengan menggunakan strategi ekspositori sangat tergantung pada langkah persiapan. Beberapa hal yang harus dilakukan dalam langkah persiapan di antaranya adalah memberikan motivasi dan memulai pelajaran dengan mengemukakan tujuan yang harus dicapai pada pembelajaran fisika.

2) Penyajian

Langkah penyajian adalah penyampaian materi pelajaran sesuai dengan persiapan yang telah dilakukan. Yang harus dipikirkan oleh setiap guru dalam penyajian adalah bagaimana agar materi pelajaran fisika dapat dengan mudah ditangkap dan dipahami oleh siswa. Oleh karena, ada beberapa hal yang harus diperhatikan dalam pelaksanaan langkah ini, yaitu penggunaan bahasa yang mudah dimengerti oleh siswa, intonasi suara yang tepat, dan menjaga kontak mata dengan siswa,

3) Korelasi

Langkah korelasi adalah langkah menghubungkan materi pelajaran fisika dengan pengalaman siswa atau dengan hal-hal lain yang memungkinkan siswa dapat menangkap keterkaitannya dalam struktur pengetahuan yang telah dimiliki oleh siswa.

4) Menyimpulkan

Langkah menyimpulkan merupakan langkah untuk memahami inti dari materi pelajaran fisikayang telah disajikan. Langkah ini sangat penting karena siswa akan dapat mengambil inti sari dari proses pembelajaran yang telah dilakukan.

5) Penerapan

Langkah penerapan adalah unjuk kemampuan siswa setelah proses pembelajaran berlangsung. Penerapan sangat penting karena melalui langkah ini guru akan dapat mengumpulkan informasi tentang penguasaan dan pemahaman materi pelajaran fisika oleh siswa. Teknik yang biasa dilakukan pada langkah ini adalah dengan membuat tugas yang relevan dengan materi yang telah disajikan dan memberikan tes yang sesuai dengan materi pelajaran yang telah disajikan. Guru juga bisa memberikan tugas berupa proyek atau produk sesuai dengan materi.

\section{KESMPULAN}

Model pembelajaran ekspositori adalah strategi pembelajaran yang menekankan kepada proses penyampaian materi secara verbal dari seorang guru kepada sekelompok siswa dengan maksud agar siswa dapat menguasai materi pelajaran secara optimal. Penguasaan konsep memberikan pengertian bahwa konsep-konsep yang diajarkan kepada siswa bukanlah sekedar bahan hapalan saja, tetapi konsep itu harus dipahami agar dapat digunakan untuk dapat memecahkan masalah yang dihadapi. Metode ceramah lebih efektif dan efisien untuk menyampaikan informasi dan pengertian.

\section{UCAPAN TERIMA KASIH}

Alhamdulillah puji syukur kepada Allah swt karena berkat kehendak dan ridha-Nya, peneliti dapat menyelesaikan artikel penelitian ini. Peneliti sadari artikel penelitian ini tidak 
akan selesai tanpa doa, dukungan dan dorongan dari berbagai pihak. Adapun dalam kesempatan ini peneliti ingin mengucapkan banyak terima kasih kepada Bapak Dr. Nana, M.Pd sebagai pembimbing dalam menyelesaikan artikel penelitian ini.

\section{REFERENSI}

Abdul Azis Wahab. (2017). Metode dan Model-Model Mengajar. Bandung: Alfabe.t

Haris, A. \& Jihan, A. 2008. Evaluasi pembelajaran. Yogyakarta: Multiprasindo

Huda, Miftahul. 2011. Cooperative Learning. Jogjakarta: Pustaka Pelajar.

Herawati, Y. (2019). Pengaruh Strategi Pembelajaran Ekspositori Terhadap Hasil Belajar Ipa Pada Siswa Kelas V Sd Negeri 116 Bengkulu Selatan.

Komalasari, Kokom. 2010. Pembelajaran Kontekstual. Bandung: Refika Aditama

Komaruddin Hidayat. 1996. Actve learning. Yogyakarta: Pustaka Insan Mandani.

Salmawati. (2014). Upaya Meningkatkan Hasil Belajar Fisika Melalui Metode Ekspositori Dengan Pemberian Kuis. Jurnal Pendidikan Fisika, 2(2), 99-109.

Sanjaya, W. 2006. Strategi pembelajaran. Jakarta: Kencana prenada media.

Sanjaya,Wina. 2006. Strategi Pembelajaran Beriontasi Standar Proses Pendidikan. Bandung: Kencana Prenada Media Group

Sigler, E. A. \& Saam, J. 2007. Constructivist or expository instructional approach: Does instruction have an effect on the accuracy of Judgement of Learning (JOL). Journal of the Scholarship of Teaching and Learning. 7(2). 22-31

Slameto, 2013. Evaluasi Pendidikan, Jakarta: Bumi Aksara Susanti, Asih Enggar. 2016. Penerapan Pembelajaran Berbasis Masalah untuk Meningkatkan Ketrampilan Berpikir Kritis Siswa Meningkatkan Ketrampilan Berpikir Kritis Siswa Kelas IX dalam Pelajaran Ekonomi Kelas IX dalam Pelajaran Ekonomi A Journal of Language, Literature, Culture, and Education A Journal of Language, POLYGLOT Vol. 12 No. 1 January 2016.

Sultan, T. 2011. Meningkatkan Hasil Belajar Fisika Melalui Pemberian Kuis Pada Proses Pembelajaran. Skripsi. FKIP UNISMUH

Trianto. 2007. Model-Model Pembelajaran Inovatif Berorientasi Konstruktivistik. Jakarta: Prestasi Publishing.

Trianto, 2009. Mendesain Model Pembelajaran Inovatif-Progresif. Jakarta: Kencana Prenada Media Group 
Uno, H. 2006. Psikologi Pendidikan. Jakarta: Bumi Aksara

Wina Sanjaya. 2006. Strategi Pembelajaran Berorientasi Standar Proses Pendidikan.Jakarta:PT. Bumi Aksara

Yuliani, Y. 2007. Pembelajaran dengan Model Advance Organizer untuk Meningkatkan Pemahaman Matematis Siswa SMA. Tesis. Bandung: FPS UPI. 